\title{
Determining Perceived Work Performance and Self-efficacy Among High-school Teachers
}

\author{
Sorina Ioana Mișu ${ }^{1}$, Monica Triculescu $^{1} \&$ Alina Petre $^{1}$ \\ ${ }^{1}$ The Bucharest University of Economic Studies, Romania \\ Correspondence: Sorina Ioana Mişu, The Bucharest University of Economic Studies, Romania. E-mail: \\ sorinaioana.misu@man.ase.ro
}

Received: June 11, 2021; Accepted: June 24, 2021; Published: June 26, 2021

\begin{abstract}
Nowadays, the concept of performance can be related to almost any field of activity, taking into consideration the fact that setting, achieving and even exceeding goals appear to be of constant interest for individuals involved in working activities. Additionally, research literature is rich in notions related to performance measurement, evaluation and management. The same interest in literature is met for the concept of teachers' self-efficacy and evidence show these two concepts are strongly related one to the other. Hence, the current study aims to bring a new perspective for these topics by analyzing work performance and self-efficacy in the field of education employees, i.e. high-school teachers, and the extent to which they perceive their self-performance and self-efficacy levels. As the present paper focuses on determining the level of the previously mentioned concepts among high school teachers from Romania, the data were gathered through an online questionnaire, answered by 603 Romanian high-school teachers and later analyzed according to quantitative research methods. The results of this study, consistent with the methodology used and within the limitations, show a high level of both perceived work performance and perceived self-efficacy among the high-school teachers. These facts could be of great interest for educational stakeholders, fellow researchers and policy makers.
\end{abstract}

Keywords: performance, efficacy, teacher performance, performance measurement, high-school teachers

\section{Introduction}

The interest for performance is an essential feature of the world we live in with an increased emphasis on valuing people's work (Radu et al., 2020) and teachers' work makes no exception. Moreover, evidence show that even before the COVID-19 pandemics there was a direction towards changing the teaching paradigm (Soare, 2008), but we need to expect an even faster and more dramatic change after more than a year of redesigning teaching. In terms of teachers' performance, these professionals should approach the educational process and the subsequent activities from the perspective of innovation, action and cooperation. The educators would be the personas that would involve themselves in the extended scholar life of pupils and they would face challenges through developing projects of educational development (Misu, 2019). As work performance is a well-researched concept and literature abounds in determining its context, key determination factors and outcomes, for the purpose of this paper, we consider relevant the idea that a high level of efficacy can lead to obtaining an increased work performance (Bourne et al., 2021). In particular, teachers' self-efficacy has been a hot topic during last years, the theories starting from Bandura's Social Cognitive Theory (Bandura, 1997), and later on evidence showed it is a multidimensional concept (Malmberg et al., 2014).

This paper's intention is to focus on these two very important concepts and analyzing them for a particular category of teachers, i.e., the high-school teachers, in order to lay grounds for further development and improvement. Finally, we consider relevant to disclaim the fact that since the study has been conducted in Romania and the answers were given by Romanian teachers, the results discussed later on might illustrate better a reality that is specific to the Romanian socio-cultural environment and which could be of more significance to the Romanian educational stakeholders. However, Romania is a member of the European Union since 2007 and given the fact we all live in a digital society, where we have access to information from all over the world in a matter of seconds, it is not forced to assume that the results obtained in this study could characterize high-school teachers from many countries and could give useful hints for stakeholders that aren't necessarily belonging to the Romanian space, but to the European one. 


\subsection{Literature Review}

Here after we shall continue with a brief summary regarding the most relevant theoretical aspects of the involved concepts.

\subsubsection{The Concept of Performance - Performance Evaluation and Performance Management}

It could be of use to set right from the beginning the fact that it can be noticed in the literature a consensus upon the evolution of simply measuring or evaluating performance into the performance management concept (Neely et al., 2005; Bititci et all, 2012; Smith et al., 2017). Hence, performance evaluation will indicate what must be measured whereas performance management represents the way in which the obtained measurements can be used to manage the organizational performance as a whole. Literature also agrees upon the central role of performance evaluation among the other dimensions of human resources.

Companies are aware that their success depends, to a great extent, on the increased performance of their employees (Rusu et al., 2016). However, even though organizations keep high focus on the performance indicators that come from the financial-accounting areas, it is admitted that a significant impact comes from employee performance appraisal (Jafari et al., 2009). Moreover, performance appraisal represents the highlight of performance management, which in turn, is in direct link to the organizational performance itself (Akinbowale et al., 2014).

The process of employee appraisal can be understood as the continuous process used for the identification, measurement and development of the individual performance in accordance with the company's strategic objectives (Aguinis, 2009).

\subsubsection{Performance in the Educational System}

Regarding teachers' performance, it drew our attention OECD's statement (2009, p.3) which claims that increasing teachers' performance could be the safest direction towards the students' achievement of knowledge and abilities. It is essential to be known the teachers'strong points as well as those aspects of their working style that could be improved. From this perspective, evaluating teachers is a vital element in improving the efficiency of the teaching process as well as the educational standards.

Some other researchers (Cook \& Mansfield, 2016) have come to the conclusion that teachers' performance, is also influenced by the level of students' abilities.

Regarding particularly university teachers, at European Union level, the performance indicators used for measuring teachers' performance usually regard students' results, the level of decreasing costs, training programs, the university's evaluation scores or infrastructure's quality (Lung(Moldovan) et al., 2012).

According to the 2018 report "Teachers' careers in Europe: accessibility, progress and support" the main aim of assessing a teacher's work regards the extent to which it fulfills efficiently its role.

\subsubsection{Efficacy in the Educational System}

One of the most important descriptions of teachers' efficacy relates to their belief in their capacity to cause desired outcomes such as achievement, motivation, engagement for all categories of students (Tschannen-Moran \& Hoy, 2001). Moreover, teacher self-efficacy is a widely researched concept within education as it affects student achievement and motivation as well as teacher performance and commitment (Bourne et al., 2021). Studies show the fact that teachers' self-efficacy is influenced by the teachers' individual characteristics such as age, gender or work experience (Fackler et al., 2021).

\subsubsection{Performance Evaluation in the Romanian Pre-University System}

It is worthy to mention the fact that in the Romanian pre-university system, 4 different evaluation processes function simultaneously: (1) the evaluation for finishing the probation time; (2) the evaluation done for the aim of career progress; (3) the evaluation done for the aim of reward; (4) the periodical evaluation of performance.

For the purpose of this paper, we are interested into discussing and further analyzing the forth type of evaluation. Hence, many recent reports (OECD Report, 2017; "Educated Romania" Report, 2017; FES Report, 2017) claim that this performance appraisal is not one lacking controversies. It is considered that the process does not offer teachers the necessary feedback, so that they can improve annually their teaching methods. Hence, it can be stated that Romania does not use the evaluation of teachers as a development instrument.

Moreover, another debatable issue regards the fact that the committee which gives the teachers' final evaluation score is composed, among others, of parents, students and local authorities' members, which raises the question to which extent these people are capable to assess a teacher's work. 


\subsection{Research Objectives and Hypotheses}

The main objective of this research study is to determine the level of the perceived work performance and perceived self-efficacy among high school teachers.

For a better understanding of the research's issues, there have been formulated a number of two main hypotheses, each of them with three other secondary hypotheses, so that the study could offer a consistent and complex image of the perceived work performance and perceived self-efficacy among high school teachers.

\subsubsection{H1: The Level of Perceived Performance among High School Teachers is High}

H1.1: The level of perceived performance equals between male and female high school teachers.

H1.2: The level of perceived performance is higher for indefinite term contract teachers than for fixed term contract teachers.

H1.3: The level of perceived performance is higher for above 40 years old teachers than for below 40 years old teachers.

\subsubsection{H2: The Level of Perceived Self-Efficacy among High School Teachers is High}

H2.1: The level of perceived self-efficacy equals between male and female high school teachers.

H2.2: The level of perceived self-efficacy is higher for indefinite term contract teachers than for fixed term contract teachers.

H2.3: The level of perceived self-efficacy is higher for above 40 years old teachers than for below 40 years old teachers.

\section{Method}

\subsection{Research Design}

In order to address the research objective of this paper, i.e., to determine the level of the perceived work performance and perceived self-efficacy among high school teachers, it was used a quantitative approach for developing the data collection. For this purpose it was preferred the investigation method developed through an online survey. It was designed and distributed through Google Forms platform and it was disseminated, via e-mail, among high-schools across Romania, which were in turn asked to disseminate it among their employed teachers. A total of 603 high-school teachers from all the country's regions have anonymously answered the survey.

\subsection{Instrumentation}

The questionnaire began with a section made of identification questions, where respondents were asked to give information about their gender, age, work contract type, number of years in the field of teaching and the type of high-school in which they work, summing up a total of 13 questions. Furthermore, for the purpose of the research's objective, two instruments were chosen, Griffin's Work Performance Scale and The Teachers' Sense of Efficacy Scale (long form). We additionally mention the fact that all questions were asked in Romanian language.

\section{Griffin's Work Performance Scale}

Griffin's Work Performance Scale aims to facilitate the process of determining the employees' self-perception of their performance (Griffin et al., 2007).

Taking into account the goal of this paper and the category of workers that is analyzed, we considered relevant to use this instrument, as at national level, there is no official instrument that quantifies the level of performance among teachers. The scale was used as indicated on Research Central website (http://researchcentral.ro/index.php?action=listateste\&ID=431).

Moreover, a teacher's ability to self-evaluate his or her performance should be very important, taking into consideration the nature of the work done. Usually, teaching activities involve a great deal of changes during a school year, so being capable to adapt and to keep teaching standards can be done with a previous thorough selfassessment regarding performance.

Griffin's work performance scale deconstructs the concept of performance into three dimensions. Hence, the first dimension is the level of proficiency and the authors claim about it that it shows the extent to which an individual fulfills the tasks that belong to him. The second dimension is the level of adaptability, which indicates the measure in which an individual adapts to changes regarding his workplace or responsibilities. Last but not least, the third dimension of Griffin's model is the level of proactivity, which is described as an individual's acts to anticipate or initiate change regarding his role responsibilities within the organization. 
All of the three dimensions belong to the individual's behavior. Additionally, this scale aims to measure the person's perception regarding his work performance at three different levels encountered at the workplace: the individual tasks, as a team member and as an organization member.

However, it is very important to mention that in the questionnaire used for this research, we have used an adapted version of Griffin's work performance scale for the particularities of a teacher's work. Hence, we have operated the following adjustments: (a) the replacement of the term organization with the term school - taking into consideration the fact that all respondents work in schools, we considered appropriate to name them in this way, as a school is a well-defined institution among the other organizations; (b) the elimination of the set of questions regarding the team member level - we took into consideration the particularities of a teacher's work and the fact that he does not work in a proper team. Regarding a teacher's work, the individual tasks are well defined, as much of his working time is dedicated to preparing classes, giving classes or assessing students' work. Secondly, the role of organization members is constantly and importantly manifested, given the great amount of interactions a teacher has with his work colleagues, principals or the administrative stuff. Hence, in the questionnaire used for this research, Griffin's work performance scale had 18 questions.

\section{Teachers' Sense of Efficacy Scale}

The second scale used for the purpose of this research is the Teachers' Sense of Efficacy Scale (Tschannen-Moran \& Hoy, 2001).

The authors of this instrument (Tschannen-Moran \& Hoy, 2001) define teachers' efficacy as a teacher's capacity to organize and put into action the necessary tasks that assure successful teaching activities. Having as a departure point the concept's definition, the scale aims to measure teachers' perception of self-efficacy levels.

Teachers' Sense of Efficacy Scale has had a significant impact in literature given the fact that a number of researchers have validated its efficiency and correctness (Duffin et al., 2012; Fives et al., 2009; Çapa et al, 2005). We considered relevant the inclusion of this scale through the instruments of this research as a high level of efficacy can lead to obtaining increased work performance.

We have chosen to use for the present research the scale's long version which has 24 questions, 8 for each of the scales dimensions. Hence, this instrument is based on three dimensions: (1) efficacy in student engagement; (2) efficacy in instructional strategies; (3) efficacy in classroom management.

\subsection{Data Analysis}

Both scales used for the purpose of this research, The Griffin Work Performance Scale and The Teachers' Efficacy Scale, are summing up scales, so the scores are obtained by summing up the items developed through Likert scales in 5 point: (1) in very little measure; (2) in little measure; (3) in some measure; (4) in a high measure; (5) in a very high measure.

Additionally, table 1 shows the correspondence between the scale's questions and the analyzed dimensions.

Table 1. The correspondence between the scale's questions and the analyzed dimensions

\begin{tabular}{|l|l|l|l|l|l|l|}
\hline & \multicolumn{5}{|c|}{ Griffin's Work Performance Scale } \\
\hline Dimension & $\begin{array}{l}\text { Individual task } \\
\text { proficiency }\end{array}$ & $\begin{array}{l}\text { Individual task } \\
\text { adaptability }\end{array}$ & $\begin{array}{l}\text { Individual } \\
\text { task } \\
\text { proactivity }\end{array}$ & $\begin{array}{l}\text { Organization } \\
\text { member } \\
\text { proficiency }\end{array}$ & $\begin{array}{l}\text { Organization } \\
\text { member } \\
\text { adaptability }\end{array}$ & $\begin{array}{l}\text { Organization } \\
\text { member } \\
\text { proactivity }\end{array}$ \\
\hline $\begin{array}{l}\text { Correspondent } \\
\text { questions }\end{array}$ & $1,2,3$ & $13,14,15$ & $7,8,9$ & $10,11,12$ & $4,5,6$ & $16,17,18$ \\
\hline & \multicolumn{5}{|c|}{ Teachers'Sense of Efficacy Scale } \\
\hline Dimension & Efficacy in student engagement & Efficacy in instructional strategies & Efficacy in classroom management \\
\hline $\begin{array}{l}\text { Correspondent } \\
\text { questions }\end{array}$ & $1,2,4,6,9,12,14,22$ & $7,10,11,17,18,20,23,24$ & $3,5,8,13,15,16,19,21$ \\
\hline
\end{tabular}

\section{Results}

For this section of the research paper, we focus on delivering an interpretation on the results that have been obtained after analyzing the answers received through the questionnaire. It is of great importance to interpret the results in 
the context of the actual scientifically knowledge available so that they can help other researchers and different other stakeholders of the topic to better understand the issues and to further develop it.

Table 2. Analysis of Demographic Variables

Demographic Variables $(N=603)$

\begin{tabular}{lll}
\hline Demographic variable & & Responses \\
\hline \multirow{2}{*}{ Gender } & Female & 490 \\
& Male & 113 \\
\hline \multirow{4}{*}{ Age (yrs) } & $20-29$ & 22 \\
& $30-39$ & 81 \\
& $40-49$ & 237 \\
\multirow{2}{*}{ Type of work contract } & $50-59$ & 214 \\
& $60+$ & 49 \\
\hline & Indefinite term & 510 \\
& Fixed term & 93 \\
\hline
\end{tabular}

Figure 1 shows that there are more female teachers among the respondents (i.e. 81\%) than there are male teachers (i.e. 19\%). This figures reflect a both Romanian and European reality. According to a 2018 report presented by the Romanian Ministry of National Education at all pre-university levels the women are majoritarian, varying from $68.2 \%$ in technical schools to $99.7 \%$ at kindergarten level. According to the same report, the trend is similar in all EU countries.

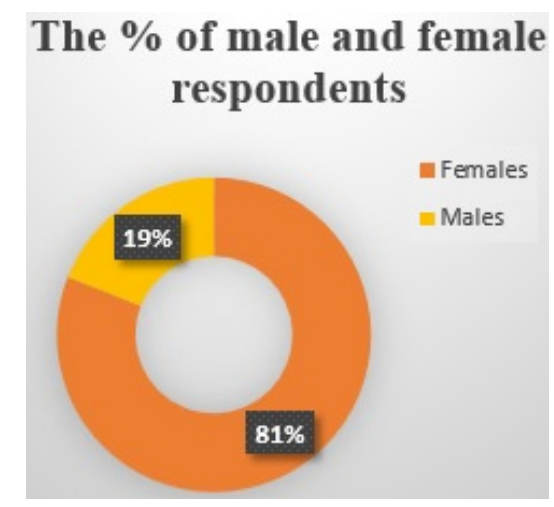

Figure 1. The percentage of male and female respondents

With respect to the number of years worked in the pre-university system, usually, the indefinite work contract group had on average 4.2 years, whereas the fixed term work contract group had on average 14.5 years (Mişu, 2020). As it can be observed in figure $2,85 \%$ of the survey's respondents are working under an indefinite term work contract.

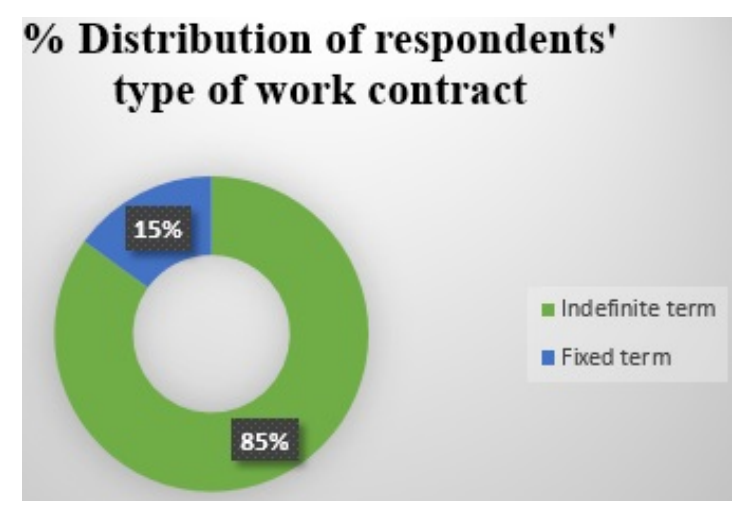

Figure 2. The distribution of respondents according to their type of work contract 
Another observation that can be made upon the demographic variables is that almost $75 \%$ of the respondents are aged between 40 and 59 years old, as it can be observed in figure 3 .

\section{$\%$ Distribution of respondents' ages}

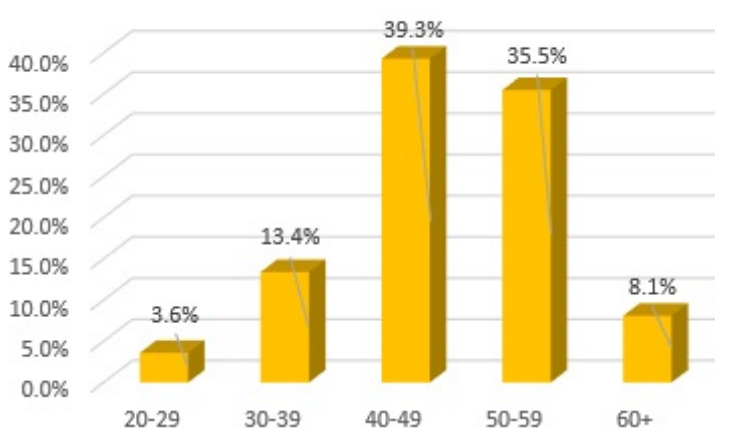

Figure 3. The distribution of respondents according to age groups

\subsection{H1: The Level of Perceived Performance among High School Teachers is High}

We have analyzed hypothesis 1 based on the results obtained through asking Griffin's work performance scale questions.

As it can be noticed in both table 3 and table 4 (see Appendix A) the median value of the given answers is 4 or 5 , both belonging to behaviors done in high or in very high measure. Hence, we can conclude that the participants of this survey regard their self-work performance as a good or very good one with regard to both their individual tasks and the ones belonging to their school member role.

\section{H1.1: The level of perceived performance equals between male and female high school teachers.}

It can be observed in tables 3 and 4 (see Appendix A) that in four out of the six categories that compose Griffin's work performance scales, male and female teachers obtain equal scores regarding the median values. The two categories where the results regarding the median values differ belong to the individual task proficiency dimension and the organization member adaptability dimension. In both of the situations, females' median scores equal 5, whereas males' are 4.

Despite these two differences, it is safe to conclude that $\mathrm{H} 1.1$ is confirmed and the level of perceived performance equals between male and female high school teachers. Moreover, an additional conclusion that can be made is that both male and female teachers have a very high level of perceived work performance. teachers.

H1.2: The level of perceived performance is higher for indefinite term contract teachers than fixed term

From the information provided by tables 3 and 4 (see Appendix A), it can be noticed that in four out six categories that compose the Griffin's work performance scale, the value of the median scores are the same between the analyzed categories of teachers. The differences appear in the organization member adaptability and the organization member proactivity. For the first, indefinite term contract teachers median values' score is 5, whereas the others median values' score is 4 . With respect to the difference occurred in the category organization member proactivity, fixed term contract teachers median values' score is 3 , whereas for the others is 4 . These median values show us that fixed term contract teachers perform only in some measure activities that would enhance their school member proactivity. This result should be not very surprising, as this category of teachers are usually employed under one year long contracts, meaning they do not have the necessary time to adjust to one school, to understand its rules and observe its issues, so that they could come up with proactive solutions.

For the rest 4 categories, in two of them, teachers' median values scores are 5 and for the others two, scores equal 4. Hence, it is safe to conclude that H1.2 is confuted and the level of perceived performance equals between indefinite term contract teachers and fixed term teachers.

However, for both indefinite term contract teachers and fixed term teachers the level of perceived work performance is only high.

H1.3: The level of perceived performance is higher for above 40 years old teachers than below 40 years old teachers. 
As it can be noticed from tables' 3 and 4 (see Appendix A) analysis, when comparing the category of teachers above 40 years old and those below 40 years old, there is no difference between the median results of these two groups of teachers.

In three of the scales' categories, the values of the mean results equal 4 and in the other three, they equal 5.

Hence, we can safely conclude that H01.3 is confuted and the level of perceived performance equals between above 40 years old teachers and below 40 years old teachers. Moreover, we can affirm that both groups of teachers have a very high level of perceived work performance.

\subsection{H2: The Level of Perceived Efficacy among High School Teachers is High}

We have analyzed hypothesis 2 based on the results obtained through asking Teachers' sense of efficacy scale questions. Tables 5, 6 and 7 indicate the results (see Appendix A).

The scores obtained by all the respondents $(\mathrm{N}=603)$ for the median values is 4 for all the three scale's dimensions (standard deviation below one for all the three dimensions). Hence, we can conclude that the hypothesis number 2 is confirmed and that the level of perceived efficacy among high school teachers is high.

\section{H2.1: The level of perceived efficacy equals between male and female high school teachers.}

With respect to the answers given by male and female teachers, it can be noticed from the above tables that the median values are equal for all the three dimensions, the value being 4 , which indicated a high level of perceived efficacy. Nevertheless, we can notice that with respect to the question how much can you do to motivate students who show low interest in school work?, males' mean scores are higher than the females' ones, as they obtain a median value of 4 whereas the females obtain a median value of 3 . Furthermore, with respect to the question "How well can you respond to difficult questions from your students?" male teachers obtain a median value of 5 and female teachers a median value of 4 . In both of the particular situations previously exposed, male teachers obtained a higher median value which might indicate a possible higher self confidence in their teaching efficacy.

Hence, $\mathrm{H} 2.1$ is confirmed.

H2.2: The level of perceived efficacy is higher for indefinite term contract teachers than fixed term teachers.

Analyzing the data from tables 5, 6 and 7 (see Appendix A), it can be observed that the median values are equal for all three dimension with respect to the answers given by indefinite term contract teachers and fixed term contract teachers. Hence, H2.2 is confuted as the level of perceived efficacy is equal between indefinite term contract teachers and fixed term teachers.

However, we can notice that regarding question how much can you do to motivate students who show low interest in school work?, the indefinite term contract teachers have a median value of 3 and the fixed term contract teachers have a median value of 4 . We could assume that the first group of teachers might have lost their own motivation to inspire students' motivation for school work. Secondly, another particular situation can be noticed regarding question "How well can you respond to difficult questions from your students?", where indefinite term contract teachers have a median value of 5 and the fixed term contract teachers have a median value of 4 . In this case, we can assume that teachers' of the first group possess more experience in handling students' difficult questions, based on their years of experience (Malmberg et al., 2014).

H2.3: The level of perceived efficacy is higher for above 40 years old teachers than below 40 years old teachers.

The analyzed data show us that the median values are equal for all three dimensions with respect to the answers given by above 40 years old teachers and below 40 years old teachers. Hence, H02.2 is confuted as the level of perceived efficacy is equal between above 40 years old teachers and below 40 years old teachers.

However, we can notice that regarding question how much can you do to motivate students who show low interest in school work?, the above 40 years old teachers have a median value of 3 and the below 40 years old teachers have a median value of 4 . This results are consistent with the ones from $\mathrm{H} 02.2$ as we could assume that the first group of teachers might have lost their own motivation to inspire students' motivation for school work. Secondly, another particular situation can be noticed regarding question how well can you respond to difficult questions from your students?, where above 40 years old teachers have a median value of 5 and the below 40 years old teachers have a median value of 4 . In this case, the results are again consistent with the ones analyzed within H02.2 and we can assume that teachers of the first group possess more experience in handling students' difficult questions, based on their experience. 


\section{Discussion}

Based on the results of the study, a number of conclusion can be made. First of all, the purpose of this study was to determine the perceived level of work performance among high-school teachers, as well as to determine the level of self-efficacy in the case of high-school teachers. From the information we have gathered, it could be concluded that high-school teachers perceive they have a high performance as well as a high sense of self-efficacy.

In terms of breaking the entire group of respondent high-school teachers into different categories, we have noticed the following. Both male and female teachers have equal scores for both the level of perceived work performance as well as the perceived self-efficacy. In terms of the groups fixed term contract teachers and indefinite term contract teachers, the results show again that there is no significant difference between the results and so is the case of above 40 years old teachers and below 40 years old teachers.

Accordingly, we can identify the fact that high -school teachers as a whole present the same features, no matter which group they belong to, regarding the level of perceived work performance and the level of perceived selfefficacy.

Therefore, it is safe to conclude that these results offer an encouraging picture regarding Romanian teachers' state of mind. Both a high level of self-efficacy and a high work performance are positively related to human resources concepts such as work engagement, work satisfaction and well-being and negatively related to stress and burnout as numerous studies have proven it (e.g.: Heuven et al., 2012; Perera et al., 2018; Granziera et al., 2019). On medium and long term, this sort of evidence could mean better policies for the educational system through a more complex understanding of its core employees. This outcome, in terms of social and economic impact, can be translated in the avoidance of high costs for the educational system.

Additionally, it must be acknowledged the fact that this research has some major limitations and its results must be used keeping in mind some important factors. Thereafter, it does not cover a representative geographical area in order to provide worldwide information (i.e. the study was conducted only with Romanian teachers). Secondly, the research was conducted during the pandemic of COVID-19, while teachers were giving online classes, context that might have influenced their perceptions. There are important chances that if the study is replicated in another geographical area, on a different sample or in a non-pandemic context, the results to differ significantly.

Nevertheless, the present paper opens the doors to continuing the investigation on how teachers perceive their work, their results and the influence they have on their students. The information could be of great interest to education stakeholders, such as the Ministries of Education, policy makers, school principals and the teachers themselves.

Last but not least, the question for both fellow researchers and stakeholders should be how this strategic human resource of a country, the teachers, can keep high their work performance and self-efficacy.

\section{References}

Aguinis, H. (2009). Performance Management, 2nd ed. Upper Saddle River, NJ: Pearson Prentice Hall

Akinbowale, M. A., Lourens, M. E., \& Jinabhai, D. C. (2014). Employee performance measurement and performance appraisal policy in an organisation. Mediterranean Journal of Social Sciences, 5(9), 342-347. https://doi.org/10.5901/mjss.2014.v5n9p342

Bititci, U., Garengo, P., Dörfler, V., Nudurupati, S. (2012). Performance Measurement: Challenges for Tomorrow. International Journal of Management Reviews, 14(3), 305-327 https://doi:10.1111/j.1468-2370.2011.00318.x

Bourne, M. J., Smeltzer, S. C., \& Kelly, M. M. (2021). Clinical teacher self-efficacy: A concept analysis. In Nurse Education in Practice (Vol. 52, p. 103029). Elsevier Ltd. https://doi.org/10.1016/j.nepr.2021.103029

Çapa, Y., Çakıroğlu, J., Sarıkaya, H. (2005). The Development and Validation of a Turkish Version of the Teachers' Sense of Efficacy. Education and Science, 30(137), 74-81

Cook, J. B., \& Mansfield, R. K. (2016). Task-specific experience and task-specific talent: Decomposing the productivity of high school teachers. Journal of Public Economics, 140, 51-72. https://doi.org/10.1016/j.jpubeco.2016.04.001

Duffin, L., French, B., Patrick, H. (2012). The Teachers' Sense of Efficacy Scale: Confirming the factor structure with beginning pre-service teachers. Teaching and Teacher Education, 28(6), 827-834, https://doi.org/10.1016/j.tate.2012.03.004

Fackler, S., Malmberg, L. E., \& Sammons, P. (2021). An international perspective on teacher self-efficacy: Personal, structural and environmental factors. Teaching and Teacher Education, 99, 103255. 
https://doi.org/10.1016/j.tate.2020.103255

Fives, H., Buehl, M. (2009). Examining the Factor Structure of the Teachers' Sense of Efficacy Scale. The Journal of Experimental Education, 78(1), 118-134. https://doi.org/10.1080/00220970903224461

Granziera, H., \& Perera, H. N. (2019). Relations among teachers' self-efficacy beliefs, engagement, and work satisfaction: A social cognitive view. Contemporary Educational Psychology, 58(February), 75-84. https://doi.org/10.1016/j.cedpsych.2019.02.003

Griffin, M. A., Neal, A., \& Parker, S. K. (2007). A new model of work role performance: Positive behavior in uncertain and interdependent contexts. Academy of Management Journal, 50(2), 327-347. https://doi.org/10.5465/AMJ.2007.24634438

Heuven, E., Bakker, A. B., Schaufeli, W. B., Huisman, N., Perera, H. N., Granziera, H., McIlveen, P., Zee, M., Koomen, H. M. Y., Yakın, M., \& Erdil, O. (2012). Profiles of teacher personality and relations with teacher self-efficacy, work engagement, and job satisfaction. Review of Educational Research, 58(April 2017), 9811015. https://doi.org/10.1016/j.sbspro.2012.09.1013

Jafari, M., Bourouni, A., \& Amiri, R. H. (2009). A new framework for selection of the best performance appraisal method. European Journal of Social Sciences, 7(3), 92-100.

Lung(Moladovan), M., IoanMoldovan, \& Alexandra, N. L. (2012). Financing Higher Education in Europe: Issues and Challenges. Procedia - Social and Behavioral Sciences, 51, 938-942. https://doi.org/10.1016/j.sbspro.2012.08.266

Malmberg, L. E., Hagger, H., \& Webster, S. (2014). Teachers' situation-specific mastery experiences: teacher, student group and lesson effects. European Journal of Psychology of Education, 29(3), 429-451. https://doi.org/10.1007/s10212-013-0206-1

Ministerul Educatiei si Cercetarii (2018). Raport privind starea invatamantului preuniversitar din Romania 20172018. Retrieved

from https://www.edu.ro/sites/default/files/Raport\%20privind $\% 20$ starea $\% 20 \% \mathrm{C} 3 \% \mathrm{AEnv} \% \mathrm{C} 4 \% 83 \% \mathrm{C} 8 \% 9 \mathrm{~B} \% \mathrm{C}$ 4\%83m\%C3\%A2ntului\%20preuniversitar\%20din\%20Rom\%C3\%A2nia_2017-2018_0.pdf

Misu, S. I. (2019). How Do High School Students Perceive the Entrepreneurial Education. Proceedings of the International Conference on Business Excellence, 13(1), 945-961. https://doi.org/10.2478/picbe-2019-0083

Mişu, S. I. (2020). Indefinite vs. fixed-term work contracts: the impact over the teachers' work-engagement. Proceedings of the International Conference on Business Excellence, 14(1), 893-905. https://doi.org/10.2478/picbe-2020-0085

Neely, A., Gregory, M., \& Platts, K. (2005). Performance measurement system design: A literature review and research agenda. In International Journal of Operations and Production Management, 25(12). https://doi.org/10.1108/01443570510633639

OECD (2009). Teacher evaluation: A conceptual framework and examples of country practices. Paris: OECD. Retrieved from https://www.oecd.org/education/school/44568106.pdf

Perera, H. N., Granziera, H., \& McIlveen, P. (2018). Profiles of teacher personality and relations with teacher selfefficacy, work engagement, and job satisfaction. Personality and Individual Differences, 120(September 2017), 171-178. https://doi.org/10.1016/j.paid.2017.08.034

Radu, C., Deaconu, A., Misu, S. I., \& Triculescu, M. (2020). The Impact of Work Investment on Performance. Amfiteatru Economic, 22(14), 1103-1120. https://doi.org/10.24818/EA/2020/S14/1103

Rusu, G., Avasilcăi, S., \& Huţu, C. A. (2016). Organizational Context Factors Influencing Employee Performance Appraisal: A Research Framework. Procedia - Social and Behavioral Sciences, 221, 57-65. https://doi.org/10.1016/j.sbspro.2016.05.090

Smith, M., Bititci, U.S. (2017). Interplay between performance measurement and management, employee engagement and performance. International Journal of Operations \& Production Management, 37(9), $1207-$ 1228. https://doi.org/10.1108/IJOPM-06-2015-0313

Soare, E. (2008). Educatia antreprenoriala.Ultima provocare a scolii. Bucuresti: V. \& I. Integral

Tschannen-Moran, M., \& Hoy, A. W. (2001). Teachers' Sense of Efficacy Scale Instrument. Teaching and Teacher Education, 17(1), 783-805. 


\section{Appendix A}

Table 3. Griffin's Work Performance Scale - Results regarding individual task statements

\begin{tabular}{|c|c|c|c|c|c|c|c|c|c|c|c|c|c|c|c|c|c|c|c|c|c|}
\hline \multirow[t]{2}{*}{$\begin{array}{c}\text { GRIFFIN'S WORK } \\
\text { PERFORMANCE SCALE }\end{array}$} & \multicolumn{3}{|c|}{$\begin{array}{l}\text { All the } \\
\text { respondents } \\
(N=603)\end{array}$} & \multicolumn{3}{|c|}{$\begin{array}{c}\text { Male } \\
\text { respondents } \\
(N=113)\end{array}$} & \multicolumn{3}{|c|}{$\begin{array}{c}\text { Female } \\
\text { respondents } \\
(N=490)\end{array}$} & \multicolumn{3}{|c|}{$\begin{array}{l}\text { Indefinite term } \\
\text { employed } \\
\text { respondents } \\
(N=510)\end{array}$} & \multicolumn{3}{|c|}{$\begin{array}{c}\text { Fixed term } \\
\text { employed } \\
\text { respondents } \\
(N=93)\end{array}$} & \multicolumn{3}{|c|}{$\begin{array}{l}\text { Below } 40 \text { years } \\
\text { old respondents } \\
\quad(N=103)\end{array}$} & \multicolumn{3}{|c|}{$\begin{array}{l}\text { Over } 40 \text { years old } \\
\text { respondents } \\
(N=500)\end{array}$} \\
\hline & M & Mdn & ST & M & Mdn & ST & $\mathbf{M}$ & Mdn & ST & M & Mdn & ST & M & Mdn & ST & M & Mdn & ST & M & Mdn & ST \\
\hline $\begin{array}{l}\text { Statements belonging to the } \\
\text { individual task proficiency } \\
\text { dimension }\end{array}$ & - & 5 & 0.67 & - & 4 & 0.77 & - & 5 & 0.64 & - & 5 & 0.65 & - & 5 & 0.80 & - & 5 & 0.71 & - & 5 & 0.67 \\
\hline $\begin{array}{l}\text { 1. You carried out the core parts of } \\
\text { your job well. }\end{array}$ & 4.49 & 5 & 0.65 & 4.36 & 4 & 0.74 & 4.52 & 5 & 0.62 & 4.50 & 5 & 0.63 & 4.42 & 5 & 0.74 & 4.46 & 5 & 0.68 & 4.50 & 5 & 0.64 \\
\hline $\begin{array}{l}\text { 2. You completed your core tasks } \\
\text { well using the standard procedures. }\end{array}$ & 4.41 & 5 & 0.71 & 4.25 & 4 & 0.80 & 4.44 & 5 & 0.69 & 4.42 & 5 & 0.68 & 4.34 & 5 & 0.86 & 4.43 & 5 & 0.76 & 4.40 & 5 & 0.70 \\
\hline \multirow[t]{2}{*}{$\begin{array}{l}\text { 3. You ensured your tasks were } \\
\text { completed properly. }\end{array}$} & 4.51 & 5 & 0.65 & 4.33 & 4 & 0.75 & 4.55 & 5 & 0.62 & 4.52 & 5 & 0.62 & 4.44 & 5 & 0.80 & 4.52 & 5 & 0.69 & 4.51 & 5 & 0.64 \\
\hline & $\mathbf{M}$ & Mdn & ST & M & Mdn & ST & M & Mdn & ST & $\mathbf{M}$ & Mdn & ST & $\mathbf{M}$ & Mdn & ST & M & Mdn & ST & M & Mdn & ST \\
\hline $\begin{array}{l}\text { Statements belonging to the } \\
\text { individual task adaptability } \\
\text { dimension }\end{array}$ & - & 4 & 0.70 & - & 4 & 0.79 & - & 4 & 0.68 & - & 4 & 0.68 & - & 4 & 0.81 & - & 4 & 0.81 & - & 4 & 0.68 \\
\hline $\begin{array}{l}\text { 13. You adapted well to changes in } \\
\text { core tasks. }\end{array}$ & 4.39 & 4 & 0.69 & 4.31 & 4 & 0.73 & 4.40 & 4 & 0.67 & 4.40 & 4 & 0.67 & 4.30 & 4 & 0.76 & 4.28 & 4 & 0.78 & 4.41 & 4 & 0.66 \\
\hline $\begin{array}{l}\text { 14. You coped with changes to the } \\
\text { way you have to do your core tasks. }\end{array}$ & 4.38 & 4 & 0.69 & 4.28 & 4 & 0.78 & 4.40 & 4 & 0.66 & 4.40 & 4 & 0.66 & 4.26 & 4 & 0.80 & 4.32 & 4 & 0.78 & 4.39 & 4 & 0.66 \\
\hline \multirow{2}{*}{$\begin{array}{l}\text { 15. You learned new skills to help } \\
\text { you adapt to changes in your core } \\
\text { tasks. }\end{array}$} & 4.34 & 4 & 0.73 & 4.22 & 4 & 0.84 & 4.37 & 4 & 0.70 & 4.36 & 4 & 0.71 & 4.22 & 4 & 0.85 & 4.25 & 4 & 0.87 & 4.36 & 4 & 0.70 \\
\hline & $\mathbf{M}$ & Mdn & ST & M & Mdn & ST & $\mathbf{M}$ & Mdn & ST & $\mathbf{M}$ & Mdn & ST & $\mathbf{M}$ & Mdn & ST & $\mathbf{M}$ & Mdn & ST & $\mathbf{M}$ & Mdn & ST \\
\hline $\begin{array}{l}\text { Statements belonging to the } \\
\text { individual task proactivity } \\
\text { dimension }\end{array}$ & - & 4 & 0.86 & - & 4 & 1.00 & - & 4 & 0.83 & - & 4 & 0.82 & - & 4 & 1.04 & - & 4 & 0.98 & - & 4 & 0.84 \\
\hline $\begin{array}{l}\text { 7. You initiated better ways of doing } \\
\text { your core tasks. }\end{array}$ & 4.13 & 4 & 0.88 & 3.97 & 4 & 0.98 & 4.45 & 4 & 0.85 & 4.42 & 4 & 0.84 & 3.97 & 4 & 1.06 & 4.02 & 4 & 1.01 & 4.15 & 4 & 0.85 \\
\hline $\begin{array}{l}\text { 8. You come up with ideas to } \\
\text { improve the way in which your core } \\
\text { tasks are done. }\end{array}$ & 4.10 & 4 & 0.87 & 3.97 & 4 & 1.05 & 4.16 & 4 & 0.82 & 4.15 & 4 & 0.83 & 3.92 & 4 & 1.06 & 4.04 & 4 & 1.02 & 4.12 & 4 & 0.84 \\
\hline $\begin{array}{l}\text { 9. You made changes to the way your } \\
\text { core tasks are done. }\end{array}$ & 4.08 & 4 & 0.84 & 3.99 & 4 & 0.95 & 4.13 & 4 & 0.81 & 4.14 & 4 & 0.81 & 3.96 & 4 & 0.99 & 4.07 & 4 & 0.92 & 4.08 & 4 & 0.82 \\
\hline
\end{tabular}

Table 4. Griffin's Work Performance Scale - Results regarding the organization member statements

\begin{tabular}{|c|c|c|c|c|c|c|c|c|c|c|c|c|c|c|c|c|c|c|c|c|c|}
\hline \multirow{3}{*}{$\begin{array}{l}\text { GRIFFIN'S WORK } \\
\text { PERFORMANCE SCALE }\end{array}$} & \multicolumn{3}{|c|}{$\begin{array}{l}\text { All the } \\
\text { respondents } \\
(N=603)\end{array}$} & \multicolumn{3}{|c|}{$\begin{array}{l}\text { Male } \\
\text { respondents } \\
(N=113)\end{array}$} & \multicolumn{3}{|c|}{$\begin{array}{l}\text { Female } \\
\text { respondents } \\
(N=490)\end{array}$} & \multicolumn{3}{|c|}{$\begin{array}{l}\text { Indefinite term } \\
\text { employed } \\
\text { respondents } \\
(N=510)\end{array}$} & \multicolumn{3}{|c|}{$\begin{array}{l}\text { Fixed term } \\
\text { employed } \\
\text { respondents } \\
(\mathrm{N}=93)\end{array}$} & \multicolumn{3}{|c|}{$\begin{array}{l}\text { Below } 40 \text { years } \\
\text { old respondents } \\
(N=103)\end{array}$} & \multicolumn{3}{|c|}{$\begin{array}{l}\text { Over } 40 \text { years old } \\
\text { respondents } \\
(N=500)\end{array}$} \\
\hline & $\mathbf{M}$ & Mdn & ST & M & Mdn & ST & $\mathbf{M}$ & Mdn & ST & M & \begin{tabular}{|l|l} 
Mdn \\
\end{tabular} & ST & $\mathbf{M}$ & Mdn & ST & $\mathbf{M}$ & Mdn & ST & M & Mdn & ST \\
\hline & - & 5 & 0.76 & - & 5 & 0.91 & - & 5 & 0.72 & - & 5 & 0.70 & - & 5 & 0.97 & - & 5 & 0.86 & - & 5 & 0.73 \\
\hline $\begin{array}{l}\text { 10. You presented a positive image of } \\
\text { the school to other people }\end{array}$ & 4.41 & 5 & 0.82 & 4.33 & 5 & 0.94 & 4.43 & 5 & 0.79 & 4.55 & 5 & 0.76 & 4.17 & 5 & 1.05 & 4.25 & 5 & 0.94 & 4.44 & 5 & 0.79 \\
\hline $\begin{array}{l}\text { 11. You defended the school if others } \\
\text { criticized it. }\end{array}$ & 4.49 & 5 & 0.75 & 4.37 & 5 & 0.97 & 4.51 & 5 & 0.69 & 4.52 & 5 & 0.70 & 4.31 & 5 & 0.97 & 4.34 & 5 & 0.87 & 4.52 & 5 & 0.72 \\
\hline \multirow[t]{2}{*}{$\begin{array}{l}\text { 12. You talked about the school in } \\
\text { positive ways. }\end{array}$} & 4.56 & 5 & 0.69 & 4.48 & 5 & 0.79 & 4.58 & 5 & 0.66 & 4.60 & 5 & 0.64 & 4.38 & 5 & 0.88 & 4.39 & 5 & 0.76 & 4.60 & 5 & 0.66 \\
\hline & M & Mdn & ST & M & Mdn & ST & M & Mdn & ST & $\mathbf{M}$ & Mdn & ST & M & Mdn & ST & M & Mdn & ST & $\mathbf{M}$ & Mdn & ST \\
\hline $\begin{array}{l}\text { Statements belonging to the } \\
\text { organization member adaptability } \\
\text { dimension }\end{array}$ & - & 5 & 0.75 & - & 4 & 0.87 & - & 5 & 0.72 & - & 5 & 0.72 & - & 4 & 0.90 & - & 5 & 0.84 & - & 5 & 0.73 \\
\hline $\begin{array}{l}\text { 4. You responded flexibly to overall } \\
\text { changes in the school (e.g., changes in } \\
\text { management). }\end{array}$ & 4.42 & 5 & 0.71 & 4.27 & 4 & 0.79 & 4.45 & 5 & 0.68 & 4.44 & 5 & 0.69 & 4.33 & 4 & 0.81 & 4.37 & 5 & 0.78 & 4.43 & 5 & 0.70 \\
\hline $\begin{array}{l}\text { 5. You coped with changes in the way } \\
\text { the school operates. }\end{array}$ & 4.33 & 4 & 0.79 & 4.10 & 4 & 0.94 & 4.38 & 5 & 0.74 & 4.35 & 4 & 0.74 & 4.16 & 4 & 1.00 & 4.19 & 4 & 0.78 & 4.35 & 4 & 0.77 \\
\hline \multirow[t]{2}{*}{$\begin{array}{l}\text { 6. You learnt skills or acquired } \\
\text { information that helped you adjust to } \\
\text { overall changes in the school. }\end{array}$} & 4.40 & 5 & 0.76 & 4.18 & 4 & 0.87 & 4.45 & 5 & 0.72 & 4.42 & 5 & 0.73 & 4.29 & 4 & 0.89 & 4.32 & 5 & 0.87 & 4.42 & 5 & 0.72 \\
\hline & M & Mdn & ST & M & Mdn & ST & M & Mdn & ST & M & Mdn & ST & M & Mdn & ST & M & Mdn & ST & M & Mdn & ST \\
\hline $\begin{array}{l}\text { Statements belonging to the } \\
\text { organization member proactivity } \\
\text { dimension }\end{array}$ & - & 4 & 1.13 & - & 4 & 1.28 & - & 4 & 1.09 & - & 4 & 1.07 & - & 3 & 1.34 & - & 4 & 1.28 & - & 4 & 1.09 \\
\hline $\begin{array}{l}\text { 16. You made suggestions to improve } \\
\text { the overall effectiveness of the school } \\
\text { (e.g. by suggesting changes to } \\
\text { administrative procedures) }\end{array}$ & 3.48 & 4 & 1.14 & 3.43 & 4 & 1.30 & 3.49 & 4 & 1.10 & 3.56 & 4 & 1.09 & 3.04 & 3 & 1.31 & 3.35 & 4 & 1.37 & 3.51 & 4 & 1.09 \\
\hline $\begin{array}{l}\text { 17. You involved yourself in changes } \\
\text { that are helping to improve the overall } \\
\text { effectiveness of the school. }\end{array}$ & 3.68 & 4 & 1.10 & 3.69 & 4 & 1.23 & 3.67 & 4 & 1.06 & 3.74 & 4 & 1.04 & 3.34 & 3 & 1.33 & 3.59 & 4 & 1.21 & 3.70 & 4 & 1.07 \\
\hline $\begin{array}{l}\text { 18. You come up with ways of } \\
\text { increasing efficiency within the } \\
\text { school. }\end{array}$ & 3.54 & 4 & 1.14 & 3.48 & 4 & 1.29 & 3.55 & 4 & 1.10 & 3.61 & 4 & 1.08 & 3.16 & 3 & 1.36 & 3.51 & 4 & 1.25 & 3.55 & 4 & 1.12 \\
\hline
\end{tabular}


Table 5. Teachers' Sense of Efficacy Scale - Results regarding the efficacy in student engagement dimension

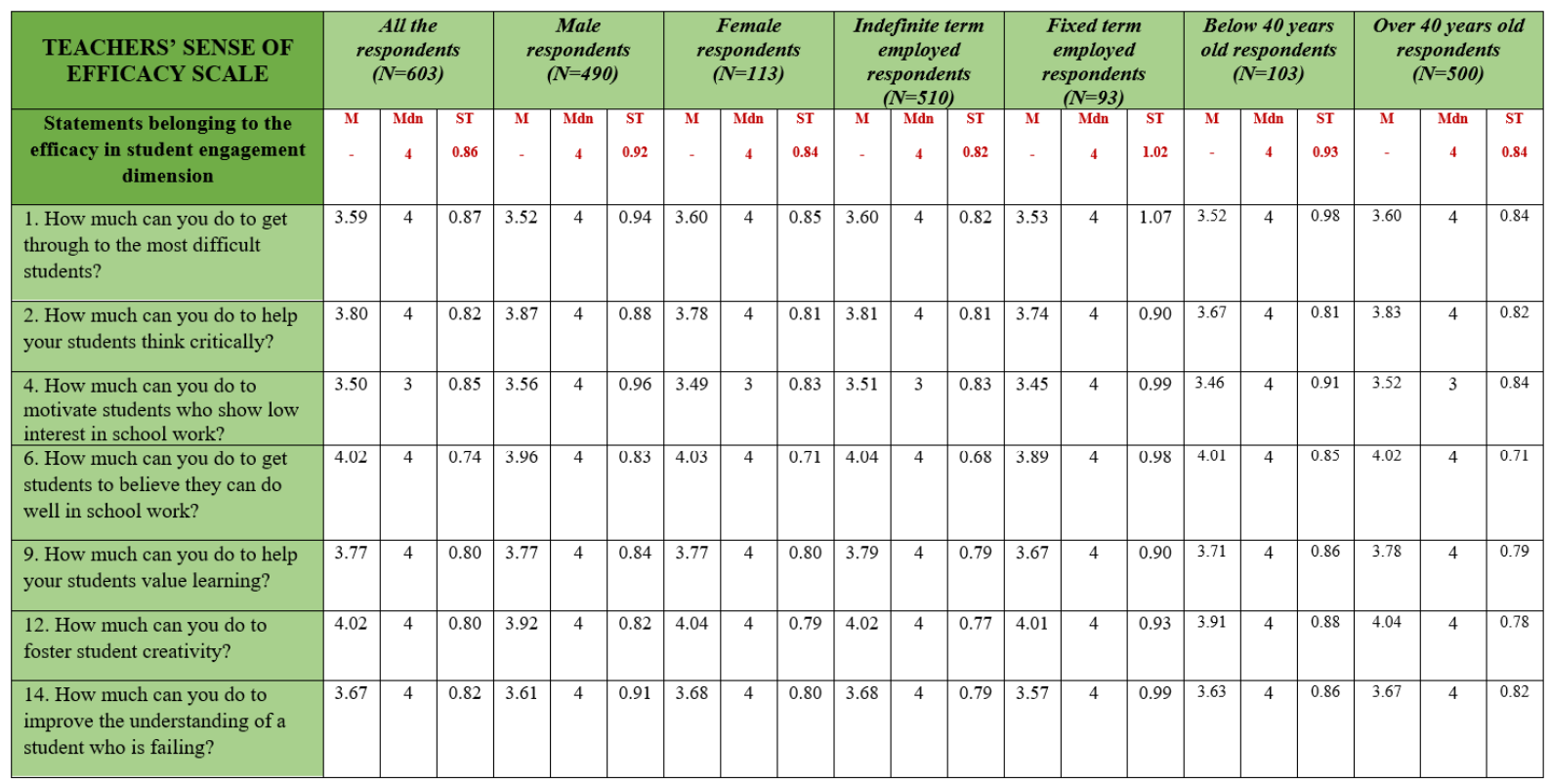

22. How much can you assist

families in helping their children

do well in school?

Table 6. Teachers' Sense of Efficacy Scale - Results regarding the efficacy in classroom management dimension

\begin{tabular}{|c|c|c|c|c|c|c|c|c|c|c|c|c|c|c|c|c|c|c|c|c|c|}
\hline \multirow{2}{*}{$\begin{array}{l}\text { TEACHERS' SENSE OF } \\
\text { EFFICACY SCALE } \\
\text { Statements belonging to the } \\
\text { efficacy in classroom } \\
\text { management dimension }\end{array}$} & \multicolumn{3}{|c|}{$\begin{array}{l}\text { All the } \\
\text { respondents } \\
(N=603)\end{array}$} & \multicolumn{3}{|c|}{$\begin{array}{l}\text { Male } \\
\text { respondents } \\
(N=490)\end{array}$} & \multicolumn{3}{|c|}{$\begin{array}{l}\text { Female } \\
\text { respondents } \\
(N=113)\end{array}$} & \multicolumn{3}{|c|}{$\begin{array}{l}\text { Indefinite term } \\
\text { employed } \\
\text { respondents } \\
(N=510)\end{array}$} & \multicolumn{3}{|c|}{$\begin{array}{l}\text { Fixed term } \\
\text { employed } \\
\text { respondents } \\
(N=93)\end{array}$} & \multicolumn{3}{|c|}{$\begin{array}{l}\text { Below } 40 \text { years } \\
\text { old respondents } \\
(N=103)\end{array}$} & \multicolumn{3}{|c|}{$\begin{array}{l}\text { Over } 40 \text { years old } \\
\text { respondents } \\
(N=500)\end{array}$} \\
\hline & M & $\begin{array}{l}\text { Mdn } \\
4\end{array}$ & $\begin{array}{l}\text { ST } \\
0.80\end{array}$ & M & $\begin{array}{l}\text { Mdn } \\
4\end{array}$ & $\begin{array}{l}\text { ST } \\
0.87\end{array}$ & $\begin{array}{l}\mathbf{M} \\
-\end{array}$ & $\begin{array}{l}\text { Mdn } \\
4\end{array}$ & $\begin{array}{l}\text { ST } \\
0.78\end{array}$ & M & $\begin{array}{l}\text { Mdn } \\
4\end{array}$ & \begin{tabular}{|l|} 
ST \\
\\
0.74
\end{tabular} & M & $\begin{array}{l}\text { Mdn } \\
4\end{array}$ & \begin{tabular}{|l|} 
ST \\
1.03
\end{tabular} & M & Mdn & $\begin{array}{l}\text { ST } \\
0.92\end{array}$ & M & Mdn & $\begin{array}{l}\text { ST } \\
0.77\end{array}$ \\
\hline $\begin{array}{l}\text { 3. How much can you do to control } \\
\text { disruptive behavior in the } \\
\text { classroom? }\end{array}$ & 4.03 & 4 & 0.82 & 4.01 & 4 & 0.88 & 4.04 & 4 & 0.81 & 4.08 & 4 & 0.77 & 3.75 & 4 & 1.01 & 3.84 & 4 & 0.94 & 4.07 & 4 & 0.79 \\
\hline $\begin{array}{l}\text { 5. To what extent can you make } \\
\text { your expectations clear about } \\
\text { student behavior? }\end{array}$ & 4.15 & 4 & 0.71 & 4.13 & 4 & 0.86 & 4.15 & 4 & 0.68 & 4.19 & 4 & 0.64 & 3.90 & 4 & 1.01 & 4.07 & 4 & 0.86 & 4.17 & 4 & 0.68 \\
\hline $\begin{array}{l}\text { 8. How well can you establish } \\
\text { routines to keep activities running } \\
\text { smoothly? }\end{array}$ & 4.15 & 4 & 0.76 & 4.10 & 4 & 0.82 & 4.19 & 4 & 0.74 & 4.22 & 4 & 0.70 & 3.92 & 4 & 0.99 & 4.16 & 4 & 0.79 & 4.17 & 4 & 0.75 \\
\hline $\begin{array}{l}\text { 13. How much can you do to get } \\
\text { children to follow classroom } \\
\text { rules? }\end{array}$ & 4.17 & 4 & 0.75 & 4.16 & 4 & 0.83 & 4.17 & 4 & 0.74 & 4.20 & 4 & 0.70 & 3.98 & 4 & 0.98 & 3.98 & 4 & 0.84 & 4.21 & 4 & 0.73 \\
\hline $\begin{array}{l}\text { 15. How much can you do to calm } \\
\text { a student who is disruptive or } \\
\text { noisy? }\end{array}$ & 3.98 & 4 & 0.83 & 4.11 & 4 & 0.86 & 3.95 & 4 & 0.82 & 4.01 & 4 & 0.78 & 3.81 & 4 & 1.03 & 3.80 & 4 & 0.93 & 4.02 & 4 & 0.80 \\
\hline $\begin{array}{l}\text { 16. How well can you establish a } \\
\text { classroom management system } \\
\text { with each group of students? }\end{array}$ & 4.14 & 4 & 0.77 & 4.09 & 4 & 0.86 & 4.16 & 4 & 0.75 & 4.19 & 4 & 0.69 & 3.86 & 4 & 1.04 & 3.93 & 4 & 0.88 & 4.19 & 4 & 0.74 \\
\hline $\begin{array}{l}\text { 19. How well can you keep a few } \\
\text { problem students form ruining an } \\
\text { entire lesson? }\end{array}$ & 3.96 & 4 & 0.84 & 3.96 & 4 & 0.96 & 3.96 & 4 & 0.80 & 4.01 & 4 & 0.77 & 3.71 & 4 & 1.09 & 3.78 & 4 & 1.00 & 4.00 & 4 & 0.79 \\
\hline $\begin{array}{l}\text { 21. How well can you respond to } \\
\text { defiant students? }\end{array}$ & 3.94 & 4 & 0.84 & 4.00 & 4 & 0.86 & 3.92 & 4 & 0.84 & 3.96 & 4 & 0.79 & 3.80 & 4 & 1.07 & 3.79 & 4 & 1.00 & 3.97 & 4 & 0.80 \\
\hline
\end{tabular}


Table 7. Teachers' Sense of Efficacy Scale - Results regarding the efficacy in instructional strategies dimension

\begin{tabular}{|c|c|c|c|c|c|c|c|c|c|c|c|c|c|c|c|c|c|c|c|c|c|}
\hline \multirow{2}{*}{$\begin{array}{l}\text { TEACHERS' SENSE OF } \\
\text { EFFICACY SCALE } \\
\begin{array}{c}\text { Statements belonging to the } \\
\text { efficacy in instructional } \\
\text { strategies dimension }\end{array}\end{array}$} & \multicolumn{3}{|c|}{$\begin{array}{l}\text { All the } \\
\text { respondents } \\
(\mathrm{N}=603)\end{array}$} & \multicolumn{3}{|c|}{$\begin{array}{c}\text { Male } \\
\text { respondents } \\
(N=490)\end{array}$} & \multicolumn{3}{|c|}{$\begin{array}{l}\text { Female } \\
\text { respondents } \\
(N=113)\end{array}$} & \multicolumn{3}{|c|}{$\begin{array}{l}\text { Indefinite term } \\
\text { employed } \\
\text { respondents } \\
(N=510)\end{array}$} & \multicolumn{3}{|c|}{$\begin{array}{l}\text { Fixed term } \\
\text { employed } \\
\text { respondents } \\
(N=93)\end{array}$} & \multicolumn{3}{|c|}{$\begin{array}{l}\text { Below } 40 \text { years } \\
\text { old respondents } \\
\quad(N=103)\end{array}$} & \multicolumn{3}{|c|}{$\begin{array}{l}\text { Over } 40 \text { years old } \\
\text { respondents } \\
(N=500)\end{array}$} \\
\hline & M & $\begin{array}{c}\text { Mdn } \\
4\end{array}$ & $\begin{array}{l}\text { ST } \\
0.80\end{array}$ & M & $\begin{array}{c}\text { Mdn } \\
4\end{array}$ & $\begin{array}{l}\text { ST } \\
0.88\end{array}$ & M & $\begin{array}{c}\text { Mdn } \\
4\end{array}$ & $\begin{array}{l}\text { ST } \\
0.79\end{array}$ & M & $\begin{array}{c}\text { Mdn } \\
4\end{array}$ & $\begin{array}{c}\text { ST } \\
0.76\end{array}$ & M & $\begin{array}{c}\text { Mdn } \\
4\end{array}$ & $\begin{array}{c}\text { ST } \\
0.98\end{array}$ & M & $\begin{array}{c}\text { Mdn } \\
4\end{array}$ & $\begin{array}{l}\text { ST } \\
0.92\end{array}$ & M & $\begin{array}{c}\text { Mdn } \\
4\end{array}$ & $\begin{array}{l}\text { ST } \\
0.78\end{array}$ \\
\hline $\begin{array}{l}\text { 7. How well can you respond to } \\
\text { difficult questions from your } \\
\text { students? }\end{array}$ & 4.40 & 5 & 0.70 & 4.42 & 5 & 0.83 & 4.40 & 4 & 0.67 & 4.44 & 5 & 0.64 & 4.20 & 4 & 0.93 & 4.26 & 4 & 0.82 & 4.43 & 5 & 0.67 \\
\hline $\begin{array}{l}\text { 10. How much can you gauge } \\
\text { student comprehension of what } \\
\text { you have taught? }\end{array}$ & 4.03 & 4 & 0.75 & 4.01 & 4 & 0.86 & 4.04 & 4 & 0.72 & 4.08 & 4 & 0.71 & 3.80 & 4 & 0.87 & 3.90 & 4 & 0.75 & 4.06 & 4 & 0.74 \\
\hline $\begin{array}{l}\text { 11. To what extent can you craft } \\
\text { good questions for your students? }\end{array}$ & 4.34 & 4 & 0.71 & 4.30 & 4 & 0.84 & 4.35 & 4 & 0.68 & 4.38 & 4 & 0.66 & 4.15 & 4 & 0.90 & 4.24 & 4 & 0.81 & 4.36 & 4 & 0.68 \\
\hline $\begin{array}{l}\text { 17. How much can you do to } \\
\text { adjust your lessons to the proper } \\
\text { level for individual students? }\end{array}$ & 4.06 & 4 & 0.83 & 4.01 & 4 & 0.94 & 4.08 & 4 & 0.80 & 4.11 & 4 & 0.78 & 3.83 & 4 & 1.01 & 3.87 & 4 & 0.97 & 4.10 & 4 & 0.79 \\
\hline $\begin{array}{l}\text { 18. How much can you use a } \\
\text { variety of assessment strategies? }\end{array}$ & 4.03 & 4 & 0.86 & 4.04 & 4 & 0.92 & 4.03 & 4 & 0.85 & 4.06 & 4 & 0.83 & 3.86 & 4 & 1.00 & 3.89 & 4 & 1.00 & 4.06 & 4 & 0.83 \\
\hline $\begin{array}{l}20 \text {. To what extent can you } \\
\text { provide an alternative explanation } \\
\text { or example when students are } \\
\text { confused? }\end{array}$ & 4.37 & 4 & 0.71 & 4.31 & 4 & 0.81 & 4.39 & 4 & 0.69 & 4.40 & 4 & 0.66 & 4.20 & 4 & 0.93 & 4.27 & 4 & 0.83 & 4.40 & 4 & 0.68 \\
\hline $\begin{array}{l}\text { 23. How well can you implement } \\
\text { alternative strategies in your } \\
\text { classroom? }\end{array}$ & 3.83 & 4 & 0.88 & 3.86 & 4 & 0.88 & 3.83 & 4 & 0.88 & 3.86 & 4 & 0.85 & 3.70 & 4 & 1.06 & 3.68 & 4 & 0.93 & 3.86 & 4 & 0.87 \\
\hline $\begin{array}{l}24 \text {. How well can you provide } \\
\text { appropriate challenges for very } \\
\text { capable students? }\end{array}$ & 4.32 & 4 & 0.78 & 4.31 & 4 & 0.83 & 4.33 & 4 & 0.76 & 4.35 & 4 & 0.74 & 4.19 & 4 & 0.96 & 4.16 & 4 & 0.97 & 4.36 & 4 & 0.73 \\
\hline
\end{tabular}

Notes: $\mathrm{M}=$ mean; $\mathrm{Mdn}=$ Median; $\mathrm{ST}=$ standard deviation

\section{Copyrights}

Copyright for this article is retained by the author(s), with first publication rights granted to the journal.

This is an open-access article distributed under the terms and conditions of the Creative Commons Attribution license (http://creativecommons.org/licenses/by/4.0/). 